\title{
Prevalence of Hepatitis B Virus Subgenotypes and Basal Core Promoter, Precore Variants in Patients with Acute Hepatitis B in Central Vietnam
}

\author{
Kazuhiko Hayashi ${ }^{a}$ Yoshiaki Katano ${ }^{a}$ Tran Xuan Chuong ${ }^{b}$ Yasushi Takeda ${ }^{a}$ \\ Masatoshi Ishigami $^{a}$ Akihiro Itoh $^{a}$ Yoshiki Hirooka $^{a}$ Isao Nakano ${ }^{a}$ \\ Tran Van Huy ${ }^{b}$ Nguyen Ngoc Minh ${ }^{b}$ Tran thi Minh Diem ${ }^{b}$ Dong thi Hoai An ${ }^{c}$ \\ Pham Hoang Phiet ${ }^{c}$ Hidemi Goto $^{a}$ \\ a Department of Gastroenterology, Nagoya University Graduate School of Medicine, Nagoya, Japan; \\ ${ }^{b}$ Hue College of Medicine and Pharmacy, Hue University, Hue, and ' University of Medicine and Pharmacy, \\ Ho Chi Minh City, Vietnam
}

\section{Key Words}

Hepatitis B virus • Acute hepatitis • Genotype •

Phylogenetic analysis

\begin{abstract}
Objective: Hepatitis B virus (HBV) has been classified into 8 genotypes that have different geographic distributions. The clinical outcomes of acute hepatitis are dependent on genotype. The aim of this study was to investigate the distribution of HBV subgenotypes and basal core promoter (BCP)/precore $(\mathrm{PC})$ regions in acute hepatitis patients in Central Vietnam to clarify the distributions and the clinical and virological differences. Methods: 27 patients with acute hepatitis B were studied. $\mathrm{HBV}$ subgenotypes and $\mathrm{BCP} / \mathrm{PC}$ variants were determined by direct sequencing of the preS, BCP/PC regions, respectively. Results: $\mathrm{HBV}$ subgenotypes $\mathrm{B} 4 / \mathrm{Ba}(\mathrm{n}=$ 22) and $\mathrm{C} 1 / \mathrm{Cs}(\mathrm{n}=5)$ were detected. Of the 27 patients, 3 developed fulminant hepatic failure, and all were infected with $\mathrm{B} 4 / \mathrm{Ba}$. Three patients had a BCP mutation, and 10 patients had a PC mutation in subgenotype B4/Ba. Three patients with $\mathrm{C} 1 / \mathrm{Cs}$ had a BCP mutation. Two of 3 patients who progressed to fulminant hepatic failure had T1762, A1764, and A1896 simultaneously. None of the patients with acute, self-
\end{abstract}

limited hepatitis carried these triple mutations. Conclusion: The prevalent HBV subgenotypes in patients with acute hepatitis B in Central Vietnam were B4/Ba and C1/Cs. BCP/PC variants have an association with the development of fulminant hepatic failure in subgenotype B4/Ba.

Copyright $\odot 2009$ S. Karger AG, Basel

\section{Introduction}

There are approximately 350 million people who are infected with hepatitis B virus (HBV) worldwide [1]. HBV infection has a variable clinical course, including selflimited acute hepatitis, fulminant hepatic failure, chronic hepatitis, and progression to cirrhosis and hepatocellular carcinoma [2]. Therefore, HBV infection is one of the world's most important health problems. HBV has been classified into 8 major genotypes on the basis of divergence of $8 \%$ in the full-length sequence, and it can be further classified into several subgenotypes [3, 4]. Each subgenotype has a unique geographic distribution and virological characteristics. Vietnam is one of the most endemic areas of HBV infection, and the prevalence of $\mathrm{HBV}$ subgenotypes in patients with chronic hepatitis in

\section{KARGER}

Fax +41613061234 E-Mail karger@karger.ch www.karger.com (c) 2009 S. Karger AG, Basel

0300-5526/09/0521-0022\$26.00/0

Accessible online at:

www.karger.com/int
Yoshiaki Katano, $\mathrm{MD}, \mathrm{PhD}$

Department of Gastroenterology

Nagoya University Graduate School of Medicine

65 Tsuruma-cho, Showa-ku, Nagoya 466-8550 (Japan)

Tel. +81 52744 2169, Fax +81 52744 2178, E-Mail ykatano@med.nagoya-u.ac.jp 
Vietnam has been reported [5-8]. HBV subgenotypes C1 and B4 are frequently found in Vietnam. Recently, genotype $\mathrm{I}$, a recombination with genotypes $\mathrm{A}$ and $\mathrm{C}$, has been reported from Northern Vietnam [8]. Vietnam has a long and narrow shape, and it has been traditionally divided into North, South, and Central regions. Most studies dealing with HBV infection were conducted in Northern and Southern Vietnam and HBV subgenotypes in patients with chronic hepatitis. Therefore, the distribution of HBV subgenotypes in patients with acute hepatitis in Central Vietnam remains unknown. Basal core promoter $(\mathrm{BCP}) /$ precore $(\mathrm{PC})$ region variants may be associated with fulminant hepatic failure in acute hepatitis [9]. However, the clinical roles of $\mathrm{BCP} / \mathrm{PC}$ variants in acute hepatitis are still controversial $[10,11]$. Relationships between $\mathrm{BCP} / \mathrm{PC}$ region variants and clinical course would depend on HBV subgenotypes and geographic distribution. The effects of BCP/PC variants in Vietnamese patients with acute hepatitis are little known. The aim of this study was to investigate the distribution of $\mathrm{HBV}$ subgenotypes and $\mathrm{BCP} / \mathrm{PC}$ regions in patients with acute hepatitis B in Central Vietnam to clarify their distributions, as well as clinical and virological differences.

\section{Patients and Methods}

Twenty-seven Vietnamese patients (14 men, 13 women) with acute hepatitis B who were treated at Hue University Hospital were enrolled in this study. The patients' mean age was $31.0 \pm 8.5$ years (range 19-49). Each patient had high titers of hepatitis B surface antigen (HBsAg) and IgM class antibody against HBV core antigen, elevated serum levels of alanine aminotransferase, and absence of antibodies against hepatitis A virus and hepatitis $\mathrm{C}$ virus. Fulminant hepatic failure was defined as the development of hepatic encephalopathy and prolongation of the prothrombin time less than $40 \%$ during the course of acute hepatitis [12]. It was necessary to discriminate between initial HBV infection and acute exacerbation of asymptomatic HBV carrier. To exclude acute exacerbation of asymptomatic HBV carrier, the patients with high risks for chronic HBV infection such as family history of HBV infection, past history of blood transfusion in childhood were excluded. Written informed consent was obtained from each patient participating in the study, and the study was carried out in accordance with the 1975 Helsinki Declaration.

\section{DNA Amplification and Sequencing}

$\mathrm{HBV}$ viral loads and direct sequencing of the preS, polymerase, and $\mathrm{PC} /$ core regions were performed using serum samples taken within 2 days after admission at hospital. HBV DNA was isolated from peripheral blood with a QIAamp DNA Mini Kit (Qiagen, Hilden, Germany). The HBV-DNA quantitative viremia load was determined using real-time PCR [13]. Nested polymerase chain reaction (PCR) analysis and direct sequencing of the preS, polymerase, and PC/core regions were performed as reported previously [14]. In brief, each $50-\mu \mathrm{l}$ PCR reaction contained $100 \mathrm{nM}$ each primer, $1 \mathrm{ng}$ template DNA, $5 \mu \mathrm{l}$ GeneAmp $10 \times$ PCR buffer, $2 \mu \mathrm{ldNTP}$, and 1.25 U AmpliTaq Gold (Applied Biosystems, Foster City, Calif., USA). Primers for the preS region were sense (TCACCTATTCTTGGGAACAAGA) and antisense (GGCACTAGTAAACTGAGCCA), and primers for the PC/core region were sense (GTTGCATGGAGACCACCGTGAAC) and antisense (CTGACTACTAATTCCCTGGATGCTGGGTCT). Amplification conditions consisted of $5 \mathrm{~min}$ at $94^{\circ}$ followed by 40 cycles of $94^{\circ}$ for $30 \mathrm{~s}, 55^{\circ}$ for $30 \mathrm{~s}$, and $72^{\circ}$ for $1 \mathrm{~min}$ in a thermal cycler (GeneAmp PCR System 9700, Applied Biosystems). The second PCR was done in the same reaction buffer with the first-round PCR product as template and the following sets of primers: for the preS region, sense (TCACCTATTCTTGGGAACAAGA) and antisense (AGAAGATGAGGCATAGCAGC), and for the PC/core region, sense (ATGTCGACAACCGACCTTGA) and antisense (GTATGGTGAGGTGAACAATG). The PCR products were separated by electrophoresis on $2 \%$ agarose gels, stained with ethidium bromide, and visualized under UV light. The PCR products were purified and then sequenced with the second-round PCR primers with a dye terminator sequencing kit (Big Dye Terminator v1.1 Cycle Sequencing Kit, Applied Biosystems) by an ABI 310 DNA Sequencer (Applied Biosystems). The neighbor-joining method [15] was used for phylogenetic analysis of the preS region to classify HBV into subgenotypes. Bootstrap analysis (1,000 replicates) was performed [16].

\section{Statistical Analyses}

The data are expressed as mean \pm SD. Contingency table analysis with Fisher's exact probability test was used for comparisons between groups; $\mathrm{p}<0.05$ was considered statistically significant. The statistical software used was SPSS (SPSS Inc., Chicago, Ill., USA).

\section{Results}

The results of the phylogenetic analyses of the HBV subgenotypes of the 27 patients with acute hepatitis B are shown in figure 1.22 patients had subgenotype $\mathrm{B} 4 / \mathrm{Ba}$, and 5 patients had subgenotype $\mathrm{C} 1 / \mathrm{Cs}$. There were $24 \mathrm{pa}-$ tients with acute self-limited hepatitis and 3 patients who developed fulminant hepatic failure. In patients with acute self-limited hepatitis, HBV subgenotypes $\mathrm{B} 4 / \mathrm{Ba}$ $(n=19)$ and C1/Cs $(n=5)$ were found. All patients who progressed to fulminant hepatic failure had HBV subgenotype $\mathrm{B} 4 / \mathrm{Ba}$. There was no distinctive clustering among patients who progressed to fulminant hepatic failure defined by phylogenetic analyses of preS region, and no specific mutation in preS region was found among patients with fulminant hepatic failure. Clinical characteristics according to clinical course and subgenotypes are shown in table 1 . The results of the $\mathrm{BCP} / \mathrm{PC}$ sequence according to HBV subgenotypes and clinical course are 
Fig. 1. Phylogenetic analysis of 27 sequences from the preS region of HBV of acute hepatitis patients and 70 reference strains from a database shown by accession number. Asterisks indicate the strain that progressed to fulminant hepatic failure. Phylogenetic analysis was performed by the neighbor-joining method with Woolly monkey HBV (AF046996) as the outgroup. The scale bar indicates genetic distance.

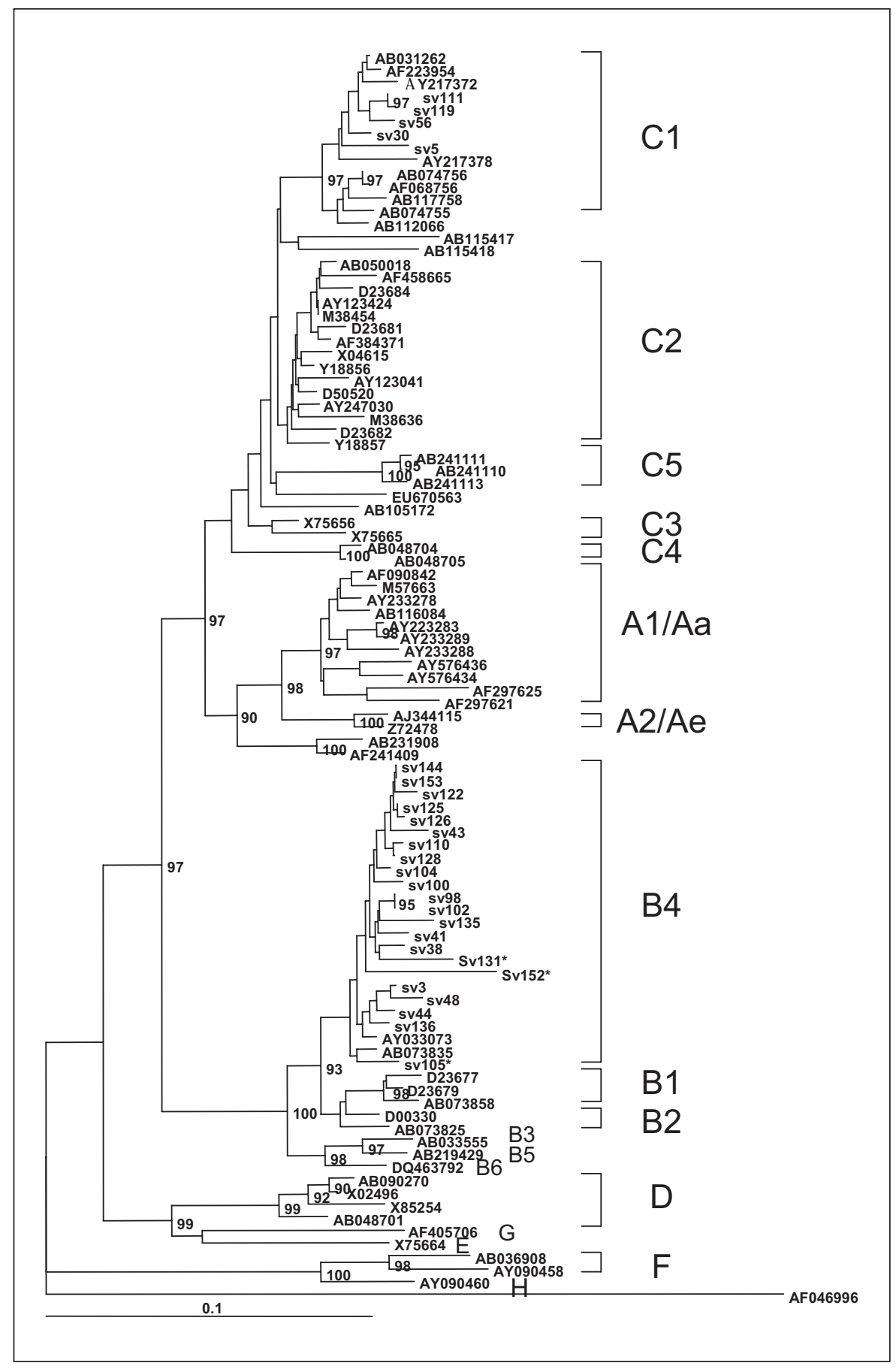

shown in figure 2. Mutations of $\mathrm{BCP}$ and $\mathrm{PC}$ regions were frequently found in nt 1754, 1762, 1764, and 1896. Six B4/ Ba subgenotypes had a G1754 mutation, but all C1/Cs subgenotypes had a T1754 mutation. BCP variants in nt1762 and nt 1764 appeared to be more frequently found in subgenotype $\mathrm{C} 1 / \mathrm{Cs}$ than in subgenotype B4/Ba (OR
$0.105 ; 95 \%$ CI $0.012-0.917 ; \mathrm{p}=0.056$ ). The majority of $\mathrm{C1} /$ Cs subgenotypes had the $\mathrm{C} 1858$ variant, and 1 patient had the T1858 variant. However, all B4/Ba subgenotypes had the T1858 variant. C1/Cs subgenotypes, which carry the C1858 variant, did not have the A1896 mutation and 10 of 22 B4/Ba subgenotypes with T1858 had the A1896 mu- 


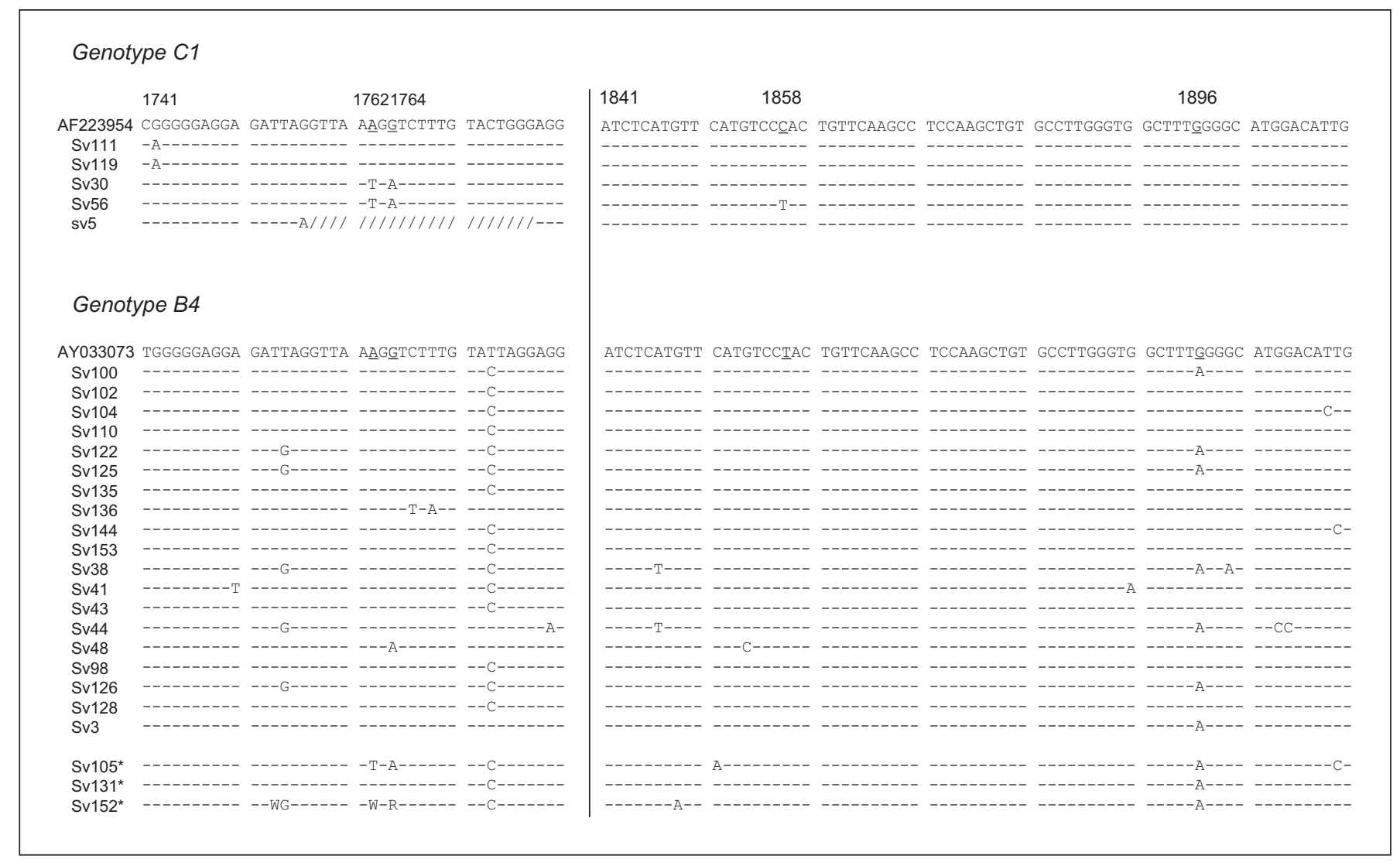

Fig. 2. Alignment of the nt sequence of 1741-1780 and 1841-1910 is shown. In the sequence alignment, dashes indicate nt identical to consensus sequence AF223954 for C1 and AY033073 for B4, respectively. Asterisks indicate the strains that progressed to fulminant hepatic failure.

Table 1. Clinical characteristics

\begin{tabular}{lcccc}
\hline & $\begin{array}{l}\text { Acute hepatitis } \\
(\mathrm{B} 4)(\mathrm{n}=19)\end{array}$ & $\begin{array}{l}\text { Acute hepatitis } \\
(\mathrm{C} 1)(\mathrm{n}=5)\end{array}$ & $\begin{array}{l}\text { Fulminant hepatitis } \\
(\mathrm{B} 4)(\mathrm{n}=3)\end{array}$ & p value \\
\hline Age, years & $31.6 \pm 8.7$ & $27.4 \pm 8.4$ & $33.0 \pm 9.0$ & $\mathrm{NS}$ \\
Male/female & $9 / 10$ & $3 / 2$ & $2 / 1$ & $\mathrm{NS}$ \\
AST, IU/l & $861.7 \pm 436.2$ & $808.6 \pm 202.4$ & $547.6 \pm 267.3$ & $\mathrm{NS}$ \\
ALT, IU/l & $1,633.6 \pm 1,526.4$ & $1,667.6 \pm 843.6$ & $845.0 \pm 91.9$ & NS \\
Total bilirubin, $\mu \mathrm{mol} / \mathrm{l}$ & $187.9 \pm 125.7$ & $112.7 \pm 72.7$ & $262.3 \pm 158.8$ & $\mathrm{NS}$ \\
Prothrombin time, $\%$ & $80.1 \pm 14.4$ & $87.1 \pm 12.9$ & $35.5 \pm 19.6$ & $<0.05$ \\
HBeAg: positive/negative* & $9 / 2$ & $1 / 3$ & $3 / 0$ & NS \\
HBV DNA levels, copies/ml & $2.8 \times 10^{7}$ & $1.4 \times 10^{7}$ & $1.2 \times 10^{7}$ & NS
\end{tabular}

Data are expressed as mean \pm SD.

$\mathrm{AST}=$ Aspartate aminotransferase; ALT = alanine aminotransferase; $\mathrm{HBV}=$ hepatitis $\mathrm{B}$ virus .

* Presence at admission and 9 patients were not available. 
tation. There were no significant differences in the other $\mathrm{BCP}$ and $\mathrm{PC}$ variants between the $\mathrm{C} 1 / \mathrm{Cs}$ and $\mathrm{B} 4 / \mathrm{Ba}$ subgenotypes. For subgenotype B4/Ba, T1762 and A1764 were detected more frequently in patients with fulminant hepatic failure $(66.7 \%)$ than in patients with acute selflimited hepatitis (5.3\%) (OR 0.024; 95\% CI 0.001-0.544; $\mathrm{p}=0.029)$. The patients with fulminant hepatic failure more frequently had A1896 (100\%) than those with acute self-limited hepatitis $(36.8 \%)(\mathrm{p}=0.052)$. Two of 3 patients with fulminant hepatic failure and no patients with acute self-limited hepatitis carried the T1762, A1764, and A1896 mutations simultaneously $(\mathrm{p}=0.010)$.

\section{Discussion}

The prevalence of HBV infection in Vietnam has been reported to be $19.0 \%$, and Vietnam is considered to be a high endemic area of HBV infection [7]. Subgenotypes $\mathrm{B} 4 / \mathrm{Ba}$ and $\mathrm{C} 1 / \mathrm{Cs}$ have been found in patients with acute hepatitis B in Central Vietnam. This distribution was similar to previous studies of patients with chronic HBV infection from Northern and Southern Vietnam, which indicates no significant regional differences in Vietnam.

The distributions of the HBV subgenotypes are changing gradually due to international interchange of patients. The study of HBV genotypes in Japanese immigrants and natives in Bolivia indicated that transmission of HBV genotypes was easy and widespread [17]. The prevalence of HBV BCP/PC variants has changed in the USA because of immigrants from endemic areas [18]. Studies from Japan and Ireland reported that the prevalence of HBV subgenotypes that were rare in Japan and Ireland appears to be increasing in patients with acute hepatitis B $[19,20]$. However, Central Vietnam was still a conservative area and did not have the same tendency. Surveillance of HBV subgenotypes will need to be continued, because $\mathrm{HBV}$ may easily spread to the general population within a short period [17, 21].

The predominant HBV subgenotype in Central Vietnam was the B4/Ba subgenotype. Genotype B of HBV was classified into 6 subgenotypes. Each subgenotype has a different distribution. HBV subgenotype B1 has only been found in Japan. Subgenotype B2 has been found throughout Asia. Subgenotype B3 has been found in Indonesia, B4 in Vietnam, and B5 in the Philippines. Subgenotype B6 was recently reported from the Arctic area [22]. Virological differences between subgenotypes have been demonstrated, and HBV genotype B could be subdivided into two major subtypes based on recombination with genotype $\mathrm{C}$ over the core promoter, $\mathrm{PC}$ region and core gene [23]. Subgenotypes without this recombination are B1 (also known as Bj) and B6. Subgenotypes with recombination are $\mathrm{B} 2, \mathrm{~B} 3, \mathrm{~B} 4$, and $\mathrm{B} 5$, which used to be called $\mathrm{Ba}$. Insufficient information is available about the clinical differences of acute hepatitis with different B subgenotypes. However, one multicenter study reported that subgenotype $\mathrm{B} 1(\mathrm{Bj})$ is an independent factor associated with the development of fulminant hepatic failure [24]. In the present study, 3 patients who developed fulminant hepatic failure were infected with subgenotype B4 (Ba), but the number of patients was very small. Further studies are needed to clarify the association between subgenotype B4 and the development of fulminant hepatic failure.

With respect to $\mathrm{BCP} / \mathrm{PC}$ variants, $\mathrm{A} 1896$ mutation is associated with fulminant hepatic failure [9]. HBV genotype B was commonly found with the A1896 mutation [25]. Seven patients with acute self-limited hepatitis had the A1896 mutation. Determination of a single mutation at 1896 has a limited ability to predict the development of fulminant hepatic failure. Two of 3 patients who progressed to fulminant hepatic failure had both T1762 and A1764 in BCP and A1896 in PC. None of the patients with acute self-limited hepatitis B carried T1762, A1764, and A1896 mutations simultaneously. These findings suggest that subgenotype $\mathrm{B} 4$ and $\mathrm{BCP} / \mathrm{PC}$ variants have an association with progression to fulminant hepatic failure. Therefore, investigation of $\mathrm{BCP} / \mathrm{PC}$ variants in subgenotype $\mathrm{B} 4$ will be useful for predicting fulminant hepatic failure and developing treatment protocols, as has been previously reported for subgenotype C2/Ce [14].

Seroconversion from HBeAg to anti-HBe antibody occurs early in patients who progressed to fulminant hepatic failure which related to A1896 in PC. However, 3 patients who developed fulminant hepatic failure with A1896 in PC were positive for HBeAg at the first day of admission. $\mathrm{HBeAg}$ seroconversion might be delayed in patients with HBV subgenotype B4. Monitoring the $\mathrm{HBeAg}$ was not performed and the number of patients was insufficient. Then further studies will be needed to conclude this issue.

The other genotype that was found in the present study was HBV subgenotype C1. Genotype $\mathrm{C}$ is classified into 5 subgenotypes, designated $\mathrm{C} 1-\mathrm{C} 5$. Subgenotype $\mathrm{C} 1$ has been reported among patients in Vietnam, Thailand, and southern areas of China, including Hong Kong. Subgenotype $\mathrm{C} 1$ frequently has $\mathrm{C} 1858$ in the $\mathrm{PC}$ region. nt 1858 and nt 1896 were the pairs in the hairpin loop of the encapsidation sequence, and pairing of C1858 and G1896 
is a stable structure. As a result, $\mathrm{C} 1858$ prevents the emergence of mutation A1896 in PC [26]. There were no patients with A1896 in subgenotype C1. This result also confirmed the virological features of nt 1858 and nt 1896 in the $\mathrm{PC}$ region. There were too few patients to conclude that subgenotype $\mathrm{C} 1$, especially with $\mathrm{C} 1858$, has a low potential for progressing to fulminant hepatic failure. However, $\mathrm{C} 1858$ may be one reason why subgenotype $\mathrm{C} 1$ strains were not detected in fulminant hepatic failure patients. The mutation at nt1896 in subgenotype B4 was useful for predicting fulminant hepatic failure, but mutation at nt1896 could not predict the progression to fulminant hepatic failure in subgenotype $\mathrm{C} 1$. The relationship of nt 1896 in the PC region with fulminant hepatic failure needs to be considered with respect to the HBV subgenotypes. nt1896 mutation depends on the HBV subgenotype. Most A genotypes have C1858, and, infrequently, they have A1896, because A1896 pairs with T1858. However, some studies reported that genotype A, which emerged with a T1858 mutation, developed to an A1896 mutation. HBV easily develops several mutations, and these minor variants were taken into consideration.

Subgenotype C1 with TCC at nucleotides 1856-1858 caused more aggressive liver disease in patients with chronic hepatitis [27], but the association between this mutation and patients with acute hepatitis is unknown. There were no patients with TCC at codon 15 of the PC region, and it was difficult to investigate the relationship between TCC at codon 15 and clinical features in patients with acute hepatitis in the present study. The difference in virological features between each subgenotype has been reported, but knowledge of the effect on the clinical course is limited. Thus, further studies are needed to reveal the impact of HBV subgenotypes on the clinical course of patients with acute hepatitis B.

The complete distinction between patients with acute exacerbation of asymptomatic HBV carrier from those with initial HBV infection who progressed to fulminant hepatic failure was the limitation of this study. One of the best ways to discriminate between initial HBV infection and acute exacerbation of asymptomatic HBV carrier was to confirm the negativity of HBsAg levels before onset of acute hepatitis by previous medical records such as blood donation screening, labor and delivery screening, or employment health screening. We could not get this information from all patients, thus some patients with acute exacerbation of asymptomatic carrier might be included in this study.

In conclusion, the prevalent $\mathrm{HBV}$ subgenotypes in patients with acute hepatitis B in Central Vietnam were B4/ $\mathrm{Ba}$ and $\mathrm{C} 1 / \mathrm{Cs}$. The progression to fulminant hepatic failure in patients with subgenotype B4 was closely associated with the simultaneous mutations of T1762 and A1764 in the BCP and A1896 in the PC region.

\section{References}

1 Kao JH, Chen DS: Global control of hepatitis $B$ virus infection. Lancet Infect Dis 2002;2: 395-403.

2 Ganem D, Prince AM: Hepatitis B virus infection - natural history and clinical consequences. N Engl J Med 2004;350:111811129.

-3 Okamoto H, Tsuda F, Sakugawa H, Sastrosoewignjo RI, Imai M, Miyakawa Y, Mayumi $\mathrm{M}$ : Typing hepatitis B virus by homology in nucleotide sequence: comparison of surface antigen subtypes. J Gen Virol 1988;69:25752583.

-4 Norder H, Courouce AM, Coursaget P, Echevarria JM, Lee SD, Mushahwar IK, Robertson BH, Locarnini S, Magnius LO: Genetic diversity of hepatitis B virus strains derived worldwide: genotypes, subgenotypes, and HBsAg subtypes. Intervirology 2004; 47: 289-309.
5 Truong BX, Seo Y, Yano Y, Ho PT, Phuong TM, Long DV, Son NT, Long NC, Kato H, Hayashi Y, Trach NK, Kasuga M: Genotype and variations in core promoter and pre-core regions are related to progression of disease in $\mathrm{HBV}$-infected patients from Northern Vietnam. Int J Mol Med 2007;19:293-299.

6 Truong BX, Yano Y, Seo Y, Phuong TM, Tanaka Y, Kato H, Miki A, Utsumi T, Azuma T, Trach NK, Mizokami M, Hayashi Y, Kasuga M: Variations in the core promoter/precore region in $\mathrm{HBV}$ genotype $\mathrm{C}$ in Japanese and Northern Vietnamese patients. J Med Virol 2007;79:1293-1304

7 Nguyen VT, McLaws ML, Dore GJ: Highly endemic hepatitis B infection in rural Vietnam. J Gastroenterol Hepatol 2007;22:20932100.

8 Tran TT, Trinh TN, Abe K: New complex recombinant genotype of hepatitis $\mathrm{B}$ virus identified in Vietnam. J Virol 2008;82:56575663.
9 Omata M, Ehata T, Yokosuka O, Hosoda K, Ohto M: Mutations in the precore region of hepatitis B virus DNA in patients with fulminant and severe hepatitis. N Engl J Med 1991;324:1699-1704.

10 Laskus T, Rakela J, Nowicki MJ, Persing DH: Hepatitis B virus core promoter sequence analysis in fulminant and chronic hepatitis B. Gastroenterology 1995;109:1618-1623.

11 Pollicino T, Zanetti AR, Cacciola I, Petit MA, Smedile A, Campo S, Sagliocca L, Pasquali M, Tanzi E, Longo G, Raimondo G: Pre-S2 defective hepatitis $B$ virus infection in patients with fulminant hepatitis. Hepatology 1997;26:495-499.

12 Perrillo RP, Aach RD: The clinical course and chronic sequelae of hepatitis B virus infection. Semin Liver Dis 1981;1:15-25.

13 Abe A, Inoue K, Tanaka T, Kato J, Kajiyama N, Kawaguchi R, Tanaka S, Yoshiba M, Kohara M: Quantitation of hepatitis B virus genomic DNA by real-time detection PCR. J Clin Microbiol 1999;37:2899-2903. 
14 Hayashi K, Katano Y, Takeda Y, Honda T, Ishigami M, Itoh A, Hirooka Y, Nakano I, Yoshioka K, Toyoda H, Kumada T, Goto H: Association of hepatitis B virus subgenotypes and basal core promoter/precore region variants with the clinical features of patients with acute hepatitis. J Gastroenterol 2008;43:558-564.

15 Saitou N, Nei M: The neighbor-joining method: a new method for reconstructing phylogenetic trees. Mol Biol Evol 1987;14: 406-425.

16 Felsenstein J: Confidence limits on phylogenies: an approach using the bootstrap. Evolution 1985;39:783-791.

- 17 Khan A, Tanaka Y, Saito H, Ebinuma H, Sekiguchi H, Iwama H, Wakabayashi G, Kamiya T, Kurbanov F, Elkady A, Mizokami M: Transmission of hepatitis B virus genotypes among Japanese immigrants and natives in Bolivia. Virus Res 2008;132:174-180.

- 18 Chu CJ, Keeffe EB, Han SH, Perrillo RP, Min AD, Soldevila-Pico C, Carey W, Brown RS Jr, Luketic VA, Terrault N, Lok AS, US HBV Epidemiology Study Group: Prevalence of HBV precore/core promoter variants in the United States. Hepatology 2003;38:619-612.
9 Hayashi K, Katano Y, Takeda Y, Honda T, Ishigami M, Itoh A, Hirooka Y, Nakano I, Yano M, Goto H, Yoshioka K, Toyoda H, Kumada T: Comparison of hepatitis $\mathrm{B}$ virus subgenotypes in patients with acute and chronic hepatitis B and absence of lamivudine-resistant strains in acute hepatitis B in Japan. J Med Virol 2007;79:366-373.

-20 Laoi BN, Crowley B: Molecular characterization of hepatitis B virus (HBV) isolates, including identification of a novel recombinant, in patients with acute $\mathrm{HBV}$ infection attending an Irish hospital. J Med Virol 2008; 80:1554-1564.

21 Hallett RL, Ngui SL, Meigh RE, Mutton KJ, Boxall EH, Teo CG: Widespread dissemination in England of a stable and persistent hepatitis B virus variant. Clin Infect Dis 2004;39:945-952.

22 Sakamoto T, Tanaka Y, Simonetti J, Osiowy C, Borresen ML, Koch A, Kurbanov F, Sugiyama M, Minuk GY, McMahon BJ, Joh T, Mizokami M: Classification of hepatitis B virus genotype $\mathrm{B}$ into 2 major types based on characterization of a novel subgenotype in Arctic indigenous populations. J Infect Dis 2007;196:1487-1492.

-23 Sugauchi F, Orito E, Ichida T, Kato H, Sakugawa H, Kakumu S, Ishida T, Chutaputti A, Lai CL, Gish RG, Ueda R, Miyakawa Y, Mizokami M: Epidemiologic and virologic characteristics of hepatitis $B$ virus genotype $\mathrm{B}$ having the recombination with genotype C. Gastroenterology 2003;124:925-932.
24 Ozasa A, Tanaka Y, Orito E, Sugiyama M, Kang JH, Hige S, Kuramitsu T, Suzuki K, Tanaka E, Okada S, Tokita H, Asahina Y, Inoue K, Kakumu S, Okanoue T, Murawaki Y, Hino K, Onji M, Yatsuhashi H, Sakugawa H, Miyakawa Y, Ueda R, Mizokami M: Influence of genotypes and precore mutations on fulminant or chronic outcome of acute hepatitis B virus infection. Hepatology 2006;44: 326-334.

25 Orito E, Ichida T, Sakugawa H, Sata M, Horiike N, Hino K, Okita K, Okanoue T, Iino S, Tanaka E, Suzuki K, Watanabe H, Hige S, Mizokami M: Geographic distribution of hepatitis $\mathrm{B}$ virus (HBV) genotype in patients with chronic HBV infection in Japan. Hepatology 2001;34:590-594.

26 Chan HL, Hussain M, Lok AS: Different hepatitis B virus genotypes are associated with different mutations in the core promoter and precore regions during hepatitis B e antigen seroconversion. Hepatology 1999;29:976984.

27 Chan HL, Tse CH, Ng EY, Leung KS, Lee KH, Tsui SK, Sung JJ: Phylogenetic, virological, and clinical characteristics of genotype $\mathrm{C}$ hepatitis B virus with TCC at codon 15 of the precore region. J Clin Microbiol 2006;44: 681-687. 